\title{
(Ir)relevance of Croatian Experience for Further EU Enlargement
}

\author{
SENADA ŠELO ŠABIĆ*
}

ABSTRACT Croatia's experience of the EU accession and that of its six-year membership is only partially relevant for the Western Balkans' EU enlargement. This is contrary to the official narrative used by the European Commission and Croatian officials. The Commission explains that Croatia's accession attests that the whole of the Western Balkans can one day join the EU. Moreover, Croatia says that EU enlargement in the Western Balkans is in its national interest. However, liberal regression in Croatia shows why in future enlargements more emphasis needs to be placed on entrenchment of liberal values. Croatia advocates enlargement, but its capacity to influence the EU or its will to constructively contribute to progress in the Western Balkan are limited.

\section{Introduction}

ince the European Union (EU) decided to open its door to former communist countries, it had three rounds of enlargement. In the so-called 'big bang enlargement' in 2004, the EU admitted ten new members three Baltic countries, four Visegrad countries, Malta, Cyprus, and Slovenia. In 2007, Bulgaria and Romania joined, and Croatia in 2013. Europeanization studies defined enlargement as a new phenomenon that belongs to the field of European integration but possesses distinctively separate characteristics in terms of policy issues, relations between states and its impact on, primarily, acceding states. Europeanization theorists explained how EU rules, in a topdown approach, are being transposed into a candidate state making significant changes in a domestic environment. ${ }^{1}$ Later work on Europeanization deepened the analysis by including the study of local actors. It was not enough to study how enlargement is affecting candidate countries, but also how these countries are affecting enlargement. Local actors are not necessarily passive recipients or responsive enthusiastic partners. More often than not, they resist change, fake reforms, or actively subvert the process. ${ }^{2}$

* Institute for Development and International Relations, Croatia

Insight Turkey Vol. 21 / No. 2 / 2019, pp. 171-187 


\section{Aware of the regional dynamic stemming from the violent dissolution of the former Yugoslavia and to balance the individual approach, the EU insisted that these countries had also to demonstrate a high level of regional cooperation}

Although the answer is more complex, let us focus on two drivers of enlargement -values and interests. Moravcik and Vachudova ${ }^{3}$ insist that pragmatic interests drive enlargement and dismiss mysticism or idealistic motivations. As much as enlargement may stir emotions, it is conducted in the 'long-term economic and geopolitical interest $^{\text {'4 }}$ of both sides. At the same time, however, notions of historic recon-

ciliation in Europe and that of liberal democratic victory drove enlargement. "Successive enlargements are making a reality of the vision of a united and peaceful continent," states a document of the Council of the EU. ${ }^{5}$ Nonetheless, debates on interests and/or values are never straightforward. Enlargement has always depended on political weighing, primarily by existing member states deciding on admission of new members. Since not all EU member states necessarily share the same interests when deciding on enlargement, if there is significant will to proceed with admitting a new member, a bargaining process to remove objections takes place. ${ }^{6}$ This bargaining process is assisted by normative peer pressure, or what Frank Schimmelfennig describes as "rhetorical action' -the strategic use of norm-based arguments."' He explained that the "European integration has been legitimated by the ideology of a pan-European community of liberal-democratic states." In other words, the EU is a project of peace and commonly shared values. If one advocates liberal values as a basis for integration and if there are applicants who claim that they espouse these values, then it is hard to deny membership to such candidates using the value argument.

The normative basis, however, is just a start. The EU requests any candidate to implement a series of reforms that should prepare it for the EU membership. To be certain that a candidate has implemented necessary political and economic conditions, the EU has designed elaborate mechanisms for monitoring and assessing reform results.

This paper starts by describing the Croatian accession experience. The next section looks at a rise of conservative political ideology in Croatia since it joined the EU. The following section looks at the country's weak political will to critically face its past. The membership experience is further assessed by looking at how Croatia implements its foreign policy, in particular because Croatia singles enlargement as one of its key foreign policy goals. The conclusion sums up the preceding debate and evaluates Croatia's role in any further enlargement taking into account the contemporary moment in the EU, the 


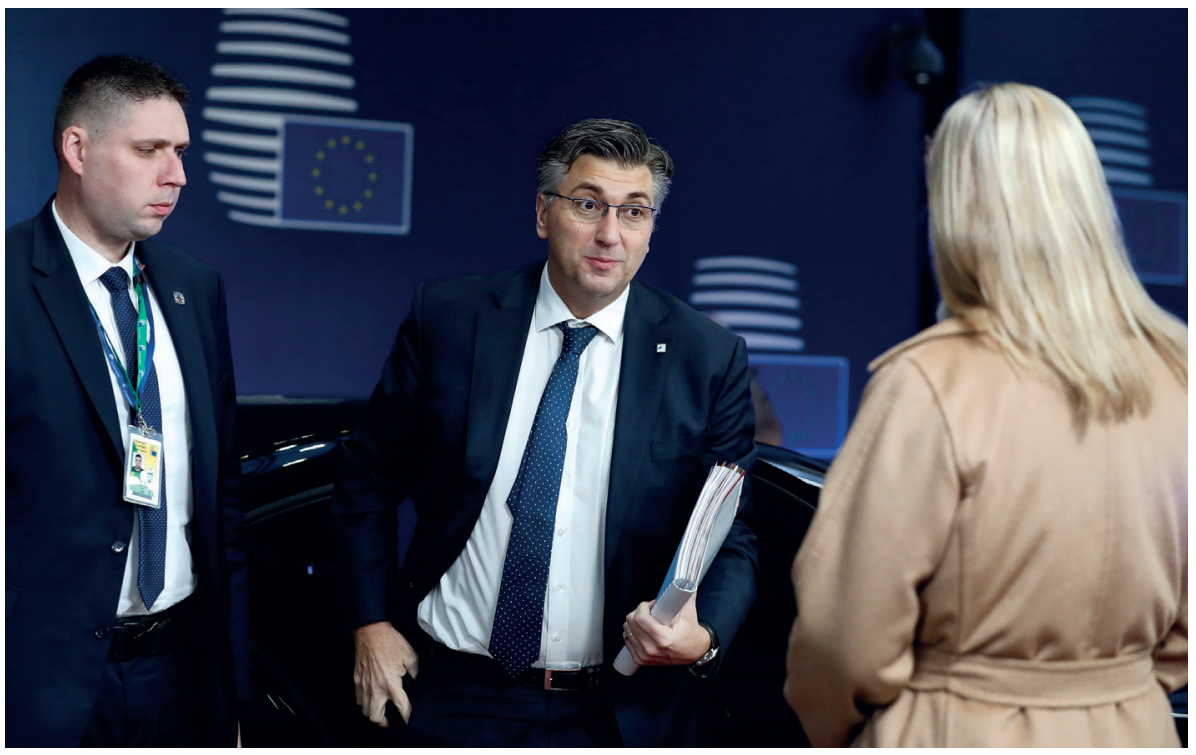

Croatia's Prime Minister Andrej Plenkovic arrives on the second day of a European summit in Brussels, December 14, 2018.

state of readiness for membership in the Western Balkan (WB) countries and Croatia's capacity (or lack of it) for a constructive contribution to enlargement.

\section{Croatian Accession Experience}

At the 2003 Thessaloniki Summit, the EU offered Stabilization and Association Agreements (SAAs) to the WB countries as a framework within which they would reform and fulfill conditions that qualify them for the EU membership. ${ }^{9}$ By granting the SAAs, EU officials expressed their "unequivocal support to the European perspective of the Western Balkan countries." ${ }^{10}$ Croatia is the first among the group of seven that has so far joined the EU, on July 1, 2013. ${ }^{11}$ The remaining six (Albania, Bosnia and Herzegovina, Kosovo, North Macedonia, Montenegro, and Serbia) are either negotiating, ${ }^{12}$ waiting to start negotiations, ${ }^{13}$ or are still potential candidates. ${ }^{14}$ The SAAs, in addition to adopting the EU acquis, also included provisions for regional cooperation and economic development. ${ }^{15}$ Unlike previous post-Cold war enlargements, WB countries would negotiate separately with the EU and their progress would be individually assessed. However, aware of the regional dynamic stemming from the violent dissolution of the former Yugoslavia and to balance the individual approach, the EU insisted that these countries had also to demonstrate a high level of regional cooperation. ${ }^{16}$

The Croatian case is relevant because of its similarity to WB countries. It is a post-communist state, with the experience of a recent war, geographically 
To succeed in instilling liberal values, a society needs leaders who espouse these values, needs a determined contribution to these values by non-political actors, and needs a thorough educational programs that trains new generations in new ways of thinking situated in the same region and was part of the same perspective for EU membership. It has cultural similarity, shares historical legacy, and has started from a similar economic and political base as its neighbors. However, among the WB states, Croatia was so far the only one capable to start and finish negotiations and become a full-fledged EU member.

When Croatia started negotiations, the EU had already learned from previous enlargements and identified problems that might arise, in particular those related to the rule of law. Therefore, the European Commission (EC) upgraded the acquis to include areas that were deemed problematic for the WB countries -justice and fundamental rights. It took into account the war crimes issues in the former Yugoslav states and the protection of minorities. It added a whole new chapter to the acquis which in the case of Croatia was the most problematic to close ${ }^{17}$ Learning from the Croatian experience, Chapter 23 is now opened at the beginning of negotiations to allow sufficient time for completion of domestic reforms.

To understand the Croatian experience, one also has to consider Croatia's unequivocal desire to join the EU. There was full consensus that this was the path to take. All the way through the accession process, Croatia never had an EU-sceptic party, certainly not an anti-EU party in the parliament. State leadership and institutions had full commitment to the EU membership.

So, the puzzle is this: if anywhere, one would expect that Europeanization takes place in a country which is small (around 4 million), which has full political consensus that EU membership is its strategic goal and which is exposed to the most elaborate criteria the EU has devised so far. If not in Croatia, then where?

However, deep social transformations take much longer periods and deeper public engagement than that which can be delivered through an EU accession process, regardless of how detailed a negotiation package is or how keen political leaders are to demonstrate that their country is fulfilling the criteria.

The EU accession is not a magic stick which changes the nature and the character of a country. It brings about important changes, but the country does not change its history nor its identity due to the technical process of negotiations. For this to happen, an intrinsic desire has to exist somewhere else, within the 
society. Usually it is missing because societies, just as individuals, do not like change and even if they try, since to change is hard, they frequently give up. To succeed in instilling liberal values, a society needs leaders who espouse these values, needs a determined contribution to these values by non-political actors, and needs a thorough educational programs that trains new generations in new ways of thinking.

Therefore, a possibility of social transformation created through EU negotiations, despite how elaborate the acquis is, has its logical limits. Expectations of what can be achieved through negotiations need to be lowered on the part of the EU. Expectations also need to be lowered on the part of an acceding country because many fall into the trap of imagining that EU membership would solve all their problems. As a rule, this does not happen. EU membership is not a panacea for the deep-ingrained challenges present in every society. In other words, negotiations to join the EU are just one aspect, albeit an important aspect of the change a society undergoes. Yet, one's history, identity, and deeply entrenched social challenges will not disappear because a country has joined the Union.

During negotiations, Croatia was expected to strengthen the rule of law with a particular focus on the protection of minority rights, establishment and functioning of strong democratic institutions operating under transparent and fair procedures, and commit to the fight against corruption. As in previous decisions on enlargement, the final decision was political.

The 2011 EC report on Croatia positively assessed Croatia's progress in the area of political criteria although it noted the need for improvements in prosecution of war crimes, judicial efficiency, effective handling of organized crime and corruption, independence and sustainability of civil society organizations, position of minorities, and cooperation with the International Criminal Tribunal for the former Yugoslavia (ICTY). ${ }^{18}$

In the course of the next two years, Croatia demonstrated improvements on all listed issues and the Commission was happy to conclude in its last monitoring report that it "is therefore confident that Croatia will be ready for membership on 1 July 2013." ${ }^{19} 10$ years of the rigorous accession process, the report explained, prepared Croatia sufficiently to effectively function within the EU, to continue fighting corruption and strengthening the rule of law. It needed to utilize what it would get as a member state "so that Croatia's participation in the EU will be a success - to the benefit of Croatia itself, of the Western Balkans region, and of the EU as a whole." ${ }^{20}$

A coalition of Croatian civil society organizations (CSO) asked for the establishment of a two-year monitoring period in the area of the rule of law, but the 


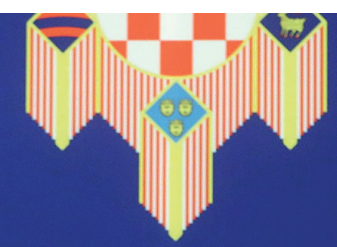

\section{PREDSJEDNICA REPUBLIKE HRVATSKE} PRESIDENT OF THE APUBLIC OF CROATIA

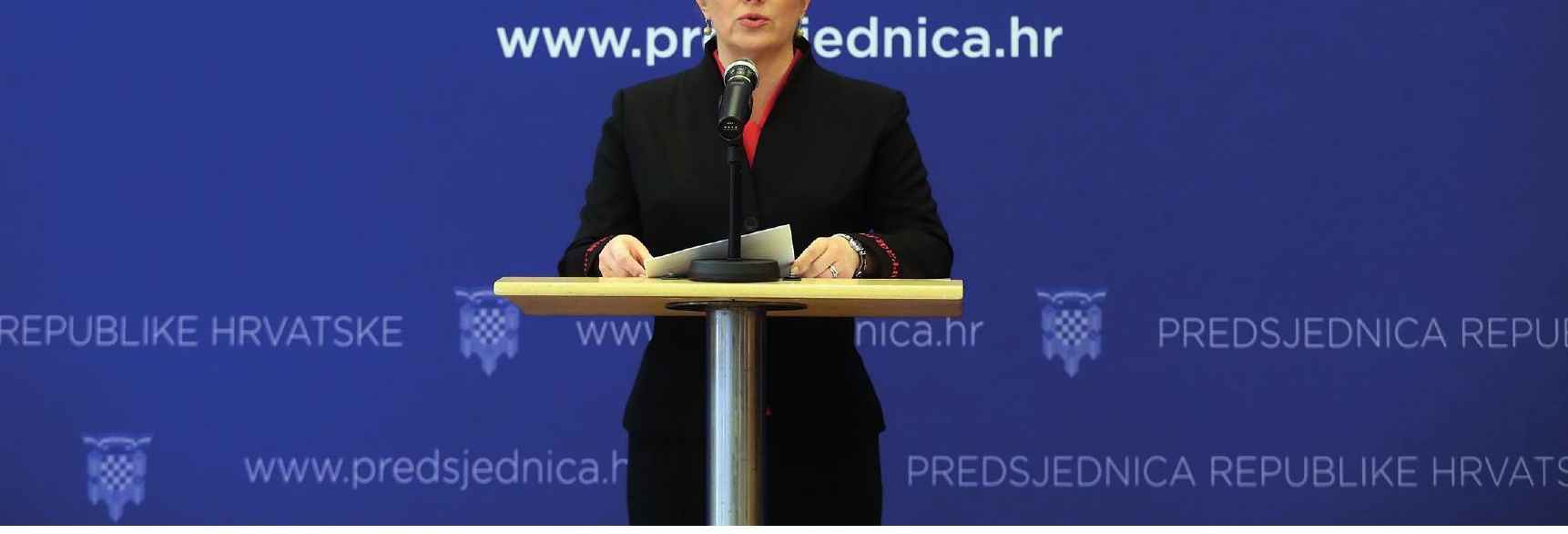

Croatian President Grabar-Kitarovic addresses a press conference in Zagreb on November 30 , 2017, a day after

the suicide of Slobodan Praljak, stating that the citizens had to admit that crimes were committed by fellow Croats in

Bosnia.

AFP / Getty Images
Commission dismissed this request. The logic behind the EC decision, apart from the strong lobbying of the Croatian government against monitoring and the lack of appetite of EU countries to grant membership to yet another unprepared state, was that Croatia was exposed to the most advanced set of accession criteria. Since they were successfully completed, the EC saw no immediate need to introduce a monitoring mechanism during a transition phase. Otherwise, it would mean that elaborate and streamlined accession criteria were insufficient to profoundly reform a small, willing and relatively developed candidate state 'prior' to its full membership. It would dismiss the lesson learned from previous enlargements that "leverage works well only 'before' accession"21 and that extended periods of time are needed for reforms to take place in certain policy areas. Both were true for Croatia -it negotiated the longest in comparison to previous enlargements and it had been exposed to the most elaborate conditionality including extensive focus on sensitive areas such as justice and fundamental rights, as well as fighting corruption and the rule of law in general. ${ }^{22}$

The CSO coalition was not convinced that the Commission made a sound judgement by deciding not to monitor Croatia's performance in selected policy 
areas. Nineteen organizations ${ }^{23}$ created a 'Platform 112 - for Croatia based on the rule of law. They listed 112 requests for improvement in the area of rule of law which included the need to continue judiciary reform, additional effort in prosecution of war crimes, and strengthening anti-corruption mechanisms. ${ }^{24}$ The number 112 was strategically chosen after an emergency assistance dial code in the EU.

Despite full political consensus on EU membership, the public started questioning this goal just when Croatia was completing negotiations. It was as if the people woke up only at the moment when they realized that their country was prepared to surrender a significant portion of its sovereignty to an organization it was set to join. It was also a reflection of the negotiations being an elite-driven process. It was conducted by the government who often justified a lack of transparency with a need to speed up the negotiations.

As required by the Croatian constitution, a national referendum on the EU accession was organized in January 2012. The turnout was 43.51 percent. Of those who voted, 66.27 percent voted in favor of the accession, while 33.13 percent opposed. ${ }^{25}$ Was such a low turnout a sign that people silently opposed membership or that they were politically indifferent about the EU, as Dejan Jović, Croatia’s political scientist, provocatively asked since just below 29 percent of the total electorate voted for the EU membership? ${ }^{26}$

Three days before July 1, 2013, the Croatian government changed a law on the European arrest warrant. This change prevented extradition of Croatian citizens on the basis of a European arrest warrant for crimes committed before August 7, 2002. This sudden change was linked to the arrest warrant issued by Germany who requested extradition of Josip Perković, a former intelligence officer in Yugoslavia and later in Croatia. Germany indicted Perković for assistance in execution of a Yugoslav emigre in 1983. This unexpected intervention into a law raised suspicion that Croatia may be defecting on its EU obligations. It was "a substantial embarrassment for the Commission, which had made rule of law the focus of particular attention in the accession process."27 However, this incident did not delay the accession ceremony. The invitations were already sent out, the flowers ordered and Zagreb's main square washed and cleaned for the historic moment. However, Angela Merkel did not show up for the ceremony. That a German chancellor, a leader of the country that 
was instrumental in Croatia's independence, a constructive supporter during accession, and a leader of the European engine would abstain from ceremonially greeting a new member, was embarrassing. The EU did not succumb. Under pressure and a credible threat of sanctions by being cut from access to EU funds, in the fall of 2013 Croatia's parliament voted new changes in the law that allowed extradition of Croatian citizens on the basis of a European arrest warrant. $^{28}$

\section{The Rise of Conservativism}

The sense of triumph of successfully completing accession negotiations was coupled with a sense of relief that the pressure had lifted. Once in the EU, a channel of pent-up energy, constrained during the accession process, opened up. In order to prove it was an eligible candidate for EU membership, Croatia had to prove that it was a liberal champion. Its successive governments consciously or unconsciously marginalized citizens whose opinion did not fit this national liberal mainstream. ${ }^{29}$

In democracy, it is all right to have dissenting opinions. We are not stronger by silencing opponents or we do not make something truer by not revealing all its elements. The strength, indeed, lies in the value of facts and arguments. If leaders honestly offer their ideas to citizens and advocate certain goals, they face possible opposition but also a potential for gaining more credible support if they convince citizens to support their goals.

The elites in Croatia, however, were "basically passive." ${ }^{30}$ It was easier to rely on the authority of Brussels and the promise of richness than to be among citizens, talk about the EU, listen to fears, answer questions, accept criticism, and be willing to democratically fight for their goals. In other words, the communication with citizens was lacking during the accession process. With this background in mind and with the knowledge of the Croatian society, the rise of conservative ideology should not come as a surprise. It was always there, linked to authoritarianism, religiosity, ethnic nationalism, gender inequality, and intolerance of sexual minorities, ${ }^{31}$ but temporarily marginalized during negotiations.

A referendum on the definition of marriage was just the first reflection of the resurgent force. On December 1, 2013, five months since Croatia joined the EU, a conservative NGO 'in the name of the family' asked voters to decide whether a marriage is a union between a man and a woman. The intention behind this initiative was a fight against same-sex marriages. Close to 38 percent of the electorate voted, out of which roughly 66 percent agreed that a marriage is only reserved for a man and a woman. The successful referendum led to a 
change of the Croatian constitution that now specifically spells out that only a male and a female can form an officially recognized marriage in Croatia. ${ }^{32}$

This, however, has a symbolic impact on the Croatian society. A law on marriage defines status of partners and their dependents, defines forms of marital union, spells out legal obligations, and regulates heritage issues. Yet, symbolism, as we know, is an important asset in politics.

This successful referendum gave additional encouragement to conservative groups. In the following years, they tried to organize a referendum on the election law with intention to curb the voting power of elected representatives of national minorities in the Croatian parliament; a referendum on the use of the Cyrillic script on public signs in ethnically mixed communities; a referendum on annulling the

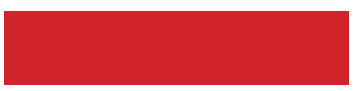

Had the ICTY passed a similar judgement during the accession talks, it is highly unlikely that Croatia's officials would react with similar disregard to decisions made by the international law courts adoption of the so-called İstanbul convention ${ }^{33}$ by the Croatian parliament in May 2018. None of these initiatives succeeded. However, initiatives to remove anti-fascist monuments from public spaces were more successful.

Conservative initiatives, coupled with endemic problems like corruption, reflect regression in political freedoms since Croatia joined the EU. Freedom House Index from 2009 registers national democratic governance indicator is at 3.50, while in 2018, they score Croatia on this indicator at 3.75, a deterioration. If one looks at other indicators measured by the Freedom House Index, the latest available report for 2018 also shows regression in the years following EU entry on civil society and judicial independence, and the rise of corruption. Therefore, the overall democratic score deteriorated from 3.61 in 2013 to 3.75 for the year $2018 .^{34}$

\section{Facing the Past}

Cooperation with the ICTY in The Hague was one of the key conditions for Croatia's EU accession. The Tribunal was established by the United Nations Security Council in 1993 to prosecute serious crimes committed during the Yugoslav wars. In 1996, the Croatian parliament adopted a constitutional law on full cooperation with the ICTY. However, cooperation was never easy because it required Croatia to extradite its citizens to the ICTY or submit sensitive military documents. In July 2001, the ICTY indicted three Croatian generals for war crimes and crimes against humanity. One of them, Ante 
Gotovina, went into hiding and could not be located until late 2005 when he was arrested by Spanish police and sent to The Hague. Gotovina's surrender became the condition for Croatia's starting EU negotiations. In 2011, the ICTY found Gotovina guilty and sentenced him to 24 years in prison. Croatia reacted with anger and support for the EU plummeted. War veterans marched in Zagreb while polls showed that the overwhelming majority of citizens saw Gotovina as a hero. In an appeal procedure a year later, the Tribunal dismissed Gotovina of all charges. His acquittal caused national celebration. The government plane was quickly dispatched to The Hague to bring home the general and the main square in Zagreb was in a matter of a few hours prepared for a festive welcome. The Croatian president concluded that the Tribunal's decision was a proof that Croatia fought a war of defense and that justice prevailed. ${ }^{35}$

The rhetoric, however, changed in November 2017 when in the appeal procedure the ICTY confirmed first instance judgements against six Bosnian Croats who in 2013 were sentenced to 111 years of imprisonment for grave breaches of Geneva Conventions, violations of the laws of war, and crimes against humanity in Bosnia and Herzegovina. Crimes included murder, deportations, inhumane treatment, rape, and sexual assaults. All six were also found guilty of participating in a 'joint criminal enterprise' (JCE) whose goal was ethnic cleansing of the Bosniak Muslim population from the territory of the so-called Herceg Bosna. In the same verdict, Croatia was found guilty of being an accomplice in the JCE. ${ }^{36}$ One of the sentenced Bosnian Croats drank poison in the chamber while the decision was being read, committing public suicide. The reaction in Croatia was different from the one in 2012. There was a strong outcry in the media and the Croatian parliament held a minute of silence for the deceased war criminal. The president addressed the UN Security Council claiming that Croatia would ask for revision of the ICTY decision, knowing very well that this was not possible. The prime minister at first expressed the same level of anguish and disregard for the ICTY ruling, but after apparently being warned by some EU capitals, changed his rhetoric. Had the ICTY passed a similar judgement during the accession talks, it is highly unlikely that Croatia's officials would react with similar disregard to decisions made by the international law courts.

In 2016, after a brief suspension, a commemoration for the victims of mass killings perpetrated by the Yugoslav army at the end of the Second World War in the fields near Bleiburg, a town in Austrian Corynthia, was reintroduced. The commemoration takes place under the auspices of the Croatian Parliament. Since 2016, the commemoration has become a place to send politically-incorrect messages garnished with Ustasha symbols (Nazi collaborators) freely displayed. Despite criticism from the Austrian local authorities, the organizers did not effectively prevent these displays. In 2019, the Catholic Church in 
Corinthya forbade any political speech at the commemoration, explaining that it "... is politically instrumentalized and is part of a political-nationalistic ritual that serves a selective experience and interpretation of history." ${ }^{\prime 37}$ Earlier in 2019, the Austrian interior ministry expanded its list of banned symbols and to those of Al-Qaida and ISIS, added "U," the Ustasha symbol. ${ }^{38}$
Croatia attempts to realize its national interests by using

EU membership as a tool towards its neighbors. This is, of course, not a novelty, but is something that Croatia vowed not to repeat

Back home, an official commemoration for victims who perished in the concentration camp Jasenovac established by the Croatian Ustasha regime during the Second World War was boycotted. In 2019, for the fourth year in the row, Croatian anti-fascists and Croatian Serb, Roma, and Jewish communities organized a separate commemoration in protest of the Ustasha salute not being banned from public use."39

"Relativization of Ustasha crimes violates the fundamental tenants of the Croatian constitution while a lack of reaction opens room for hatred" is the crux of a report published in late 2018 by the Croatian ombudswoman. ${ }^{40}$ Relativization of past crimes is a deterioration of the fundamental values that Croatia claims to espouse.

\section{Foreign Policy Focus}

Croatia joined the EU with a pledge of its foreign minister Vesna Pusić that Croatia's role in the EU would be, among others, to strongly advocate the accession of six WB countries into the EU: "The 2004 enlargement represented the end of the Cold War, the one in 2007 was territory marking, while this one is the 'enlargement with a mission' for the region." ${ }^{41}$ This is the position maintained by consecutive Croatian politicians. A crux of Croatia’s foreign policy remains the focus on its immediate neighborhood. ${ }^{42}$

The Croatian official position is that its EU membership allows it to effectively pursue its national interests while contributing to strengthening the EU. However, to translate this message into action is a different challenge. Dejan Jović, one of the most articulate foreign policy analysts, says that Croatia must rethink its foreign policy. He sees problems not only in absence of clear foreign policy goals, but also in the implementation of few selected goals. ${ }^{43}$ Croatia's focus on neighboring countries, primarily Bosnia and Herzegovina $(\mathrm{BiH})$ and Serbia are, in Jovićs view, a wrong foreign policy orientation. Croatia claimed that by joining the EU it had left the Balkans, but now finds itself "in a para- 
To expect WB countries to fully harmonize their national laws with the acquis having structural problems such as limited administrative capacity on top of problems of democratic governance and economic underdevelopment in a matter of years is waiting for a miracle to happen doxical situation of wanting to be influential in a region that it claims to have abandoned." 44

Croatia attempts to realize its national interests by using EU membership as a tool towards its neighbors. This is, of course, not a novelty, but is something that Croatia vowed not to repeat. In October 2011, the Croatian parliament adopted a 'Declaration on Instigating European Values in Southeast Europe' in which it pledged to support EU enlargement, and promised not to use open bilateral issues to block its neighbors from the EU accession. ${ }^{45}$ The EC recognized the Declaration as contribution to regional cooperation and good neighborly relations, "an essential part of Croatia’s process of moving towards the European Union." ${ }^{46}$ However, despite the official rhetoric, what has been seen in practice is a different story. Jović explained that Croatia is very active, through European and other international channels, to communicate its position and try to influence international policy making towards $\mathrm{BiH}$. Croatian members of the European Parliament, for example, "exploit their function not only to ensure the achievement of the objectives of Croatian politics towards Bosnia and Herzegovina, but also to help Bosnian Croats to achieve their particular goals." 47

Croatia's image among European diplomats is tainted by what some see as "an exclusive national view of Bosnia, not a European one." 48 Stability in Croatia's neighborhood is its desired objective, but it remains unclear how Croatia plans to achieve it by upsetting its neighborhood? Yet, Croatia's ability to have a significant impact on European policy making towards the WB is limited. The latest European Council on Foreign Relations survey finds that Croatia has the second lowest capacity in the EU to generate support and build a coalition if it were to come up with an initiative. ${ }^{49}$

\section{Conclusion}

In the nearly six years since Croatia joined the European Union, not much could have changed dramatically. Any expectations that envisaged profound, deep, and, at the same time, quick changes were unrealistic. The membership is not a solution for all problems a country has. If a country joined the EU with unresolved issues they would, in all likelihood, continue to exist. Entrench- 


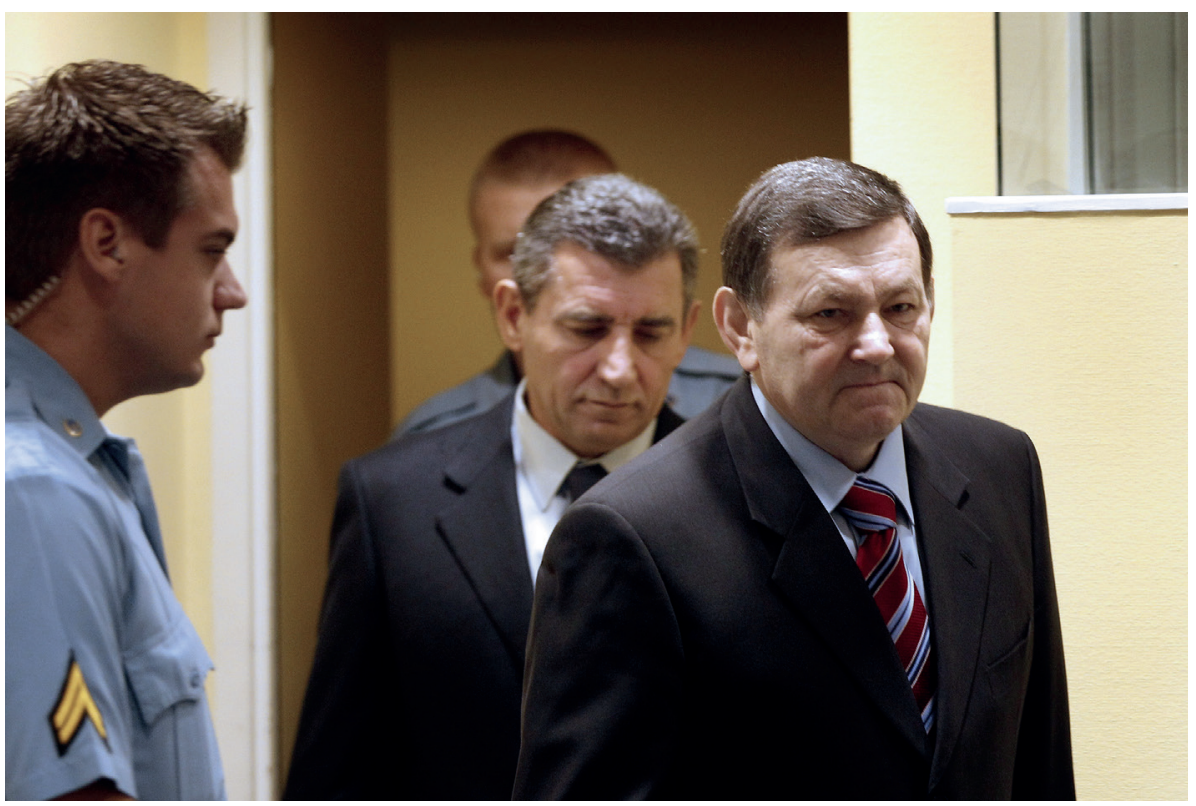

Former Croatian Army Generals Mladen Markac (R) and Ante Gotovina (C) enter the courtroom of the ICTY to attend their appeal judgement in The Hague, on November 16 , 2012.

ment of values and profound social changes are generational work and cannot be achieved during an accession process regardless how sophisticated it may be. Croatia, as a small country of around four million people, was submitted to the most elaborate accession criteria, it had domestic political consensus on EU membership and its individual negotiations with the EU lasted nearly a decade. In comparison to the remaining six WB countries, it was at the top of its class. Yet, despite full training, to play in the top EU league requires a much longer training time.

It is commendable that Croatia advocates further enlargement. However, Croatia's neighbors and the EU frequently express strong reservations towards its activities. Why is there a gap between rhetoric and action? Croatia obviously views its role quite differently from its critics. It also too often approaches neighborly relations with a zero-sum mentality where Croatia loses if its neighbor gains. It is, of course, not unique in having this zero-sum mentality, but as an EU member, it possesses more power than its neighbors and could consciously change patterns of engagement by demonstrating tolerance, fairness, and positive will.

Yet, with or without a favorable approach, Croatia's influence on the WB enlargement is limited. It is a small country that was the last to join the EU. Its preferences are relevant, but cannot significantly influence the position of other EU members. The enlargement is influenced more by WB problems such as weak democratic institutions, high corruption, low human rights standards, 
Choosing to pursue a narrow nationalist agenda in the WB rather than a broader European approach in its neighborhood, Croatia signals that an individual approach to enlargement in the WB is a bad policy and economic hardships. The new enlargement strategy presented by the EC in early 2018, starts with the warning that the WB "countries show clear elements of state capture, including links with organized crime and corruption at all levels of government and administration." ${ }^{50}$ To expect WB countries to fully harmonize their national laws with the acquis having structural problems such as limited administrative capacity on top of problems of democratic governance and economic underdevelopment in a matter of years is waiting for a miracle to happen. The engagement between the EU and the WB in the future needs to reassess the existing enlargement approach. If the EU wants to "secure and stabilize its backyard,"51 it will have to reassess its approach by an out-of-the-box thinking, beyond current enlargement logic.

The situation in the EU significantly impacts further enlargement. The 2008 financial crisis, the Russian annexation of Crimea, the war in Ukraine, an assertive China, strenuous transatlantic relations, the rise of populism following the 2015 refugee crisis, and Brexit have changed the EU during the last decade. Challenges from within absorb European policy debate leaving little room for contemplating any new enlargement. Deepening vs. broadening has always been a part of the enlargement debate. Illiberal tendencies and dysfunctional rule of law in some countries which joined the EU since 2004, negatively impact enlargement. ${ }^{52}$

Croatia continues to advocate EU enlargement as its national priority. In the first half of 2020, it will chair the EU presidency in the framework of which it will organize a high-level summit on WB enlargement. The expectations are high in Zagreb, but a fair assessment of its ability to significantly push for the enlargement are lacking. This is due to the internal crises in the EU and the low preparedness, in general, of WB countries. Croatia's performance in the $\mathrm{EU}$ is also discouraging enlargement. Choosing to pursue a narrow nationalist agenda in the WB rather than a broader European approach in its neighborhood, Croatia signals that an individual approach to enlargement in the WB is a bad policy. It objected to a Slovenian blockade, but as a member in all likelihood will use its veto power to seek concessions from its neighbors. This slows down the enlargement, undermines trust, and negatively affects regional cohesion.

Croatia's experience of enlargement would be relevant if enlargement were a technical exercise. It never was and it will be even less so in the future. Beyond 
trying to improve its domestic situation and being a relatively decent and generous neighbor, Croatia cannot do much more for enlargement. If and when new enlargement does take place, it will be under circumstances very different from those experienced in the decade between 2004 and 2013.

\section{Endnotes}

1. Frank Schimmelfennig and Ulrich Sedelmeier, The Europeanization of Central and Eastern Europe (Ithaca, NY: Cornell University Press, 2005); Tanja Börzel and Thomas Risse, "When Europe Hits Home: Europeanization and Domestic Change," European Integration online Papers (EloP), Vol. 4, No. 15 (2000).

2. Arolda Elbasani, "Europeanization Travels to the Western Balkans: Enlargement Strategy, Domestic Obstacles and Diverging Reforms," in Arolda Elbasani (ed.), European Integration and Transformation in the Western Balkans: Europeanization or Business as Usual? (Abingdon: Routledge, 2013), pp. 3-22; Heather Grabbe, "Six Lessons of Enlargement Ten Years On: The EU's Transformative Power in Retrospect and Prospect," Journal of Common Market Studies, Vol. 52, Annual Review (2014), pp. 40-56.

3. Andrew Moravchik and Milada Anna Vachudova, "National Interest, State Power and EU Enlargement," Perspectives, No. 19 (Winter 2002/2003), pp. 21-31.

4. Moravchik and Vachudova, "National Interest, State Power and EU Enlargement."

5. "A Secure Europe in a Better World - European Security Strategy," Council of the EU, (December 12, 2003), retrieved from https://www.cvce.eu/content/publication/2004/10/11/1df262f2-260c-486f-b414 -dbf8dc112b6b/publishable_en.pdf.

6. Moravchik and Vachudova, "National Interest, State Power and EU Enlargement."

7. Frank Schimmelfennig, "The Community Trap: Liberal Norms, Rhetorical Action and the Eastern Enlargement of the European Union," International Organization, Vol. 55, No. 1 (Winter 2001), p. 48.

8. Schimmelfennig, "The Community Trap."

9. Florian Bieber (ed.), EU Conditionality in the Western Balkans, (Abingdon: Routledge, 2012).

10. "EU-Western Balkans Summit Declaration," Council of the EU, Press Release 10229/03 (June 21, 2003), retrieved from https://www.consilium.europa.eu/ueDocs/cms_Data/docs/pressdata/en/misc/76291. pdf.

11. Croatia started negotiations for the European Union membership on October 3, 2005. After eight years of intense negotiations, Croatia joined the Union on July 1, 2013.

12. Montenegro and Serbia.

13. Albania and North Macedonia.

14. Bosnia and Herzegovina and Kosovo.

15. Tanja Miščević and Mojmir Mrak, "The EU Accession Process: Western Balkans vs. EU-10," Politička misao, Vol. 54, No. 4 (2017), pp. 185-204.

16. Dimitar Bechev, Constructing South East Europe: The Politics of Balkan Regional Cooperation, (Hampshire: Palgrave Macmillan, 2011).

17. Later on, based on the experience of negotiations with Croatia, the Commission would request that the Chapter 23 be open immediately at the beginning of negotiations, as was the case with Montenegro.

18. "Croatia 2011 Progress Report," European Commission, (October 12, 2011), retrieved from https:// ec.europa.eu/neighbourhood-enlargement/sites/near/files/pdf/key_documents/2011/package/hr_ rapport_2011_en.pdf.

19. "Monitoring Report on Croatia's Accession Preparations," European Commission, (March 26, 2013), retrieved from http://ec.europa.eu/helpdesk/delete/elarg/docs/news/20130326_report_final.pdf, p. 15.

20. "Monitoring Report on Croatia's Accession Preparations." 
21. Milada Anna Vachudova, "EU Enlargement and State Capture in the Western Balkans," in Jelena Džankić, Soeren Keil, and Marko Kmezić (eds.), The Europeanisation of the Western Balkans. A Failure of Conditionality?, (Hampshire: Palgrave Macmillan, 2019), p. 66.

22. Arolda Elbasani and Senada Šelo Šabić, "Rule of Law, Corruption and Democratic Accountability in the Course of EU Enlargement," Journal of European Public Policy, Vol. 25, No. 9 (2018).

23. They were supported by additional 47 CSOs.

24. "Civil Society Assessment Report of the Croatian Government Performance in View of 112 Requests," 112. The Platform of Human Rights Organizations in Croatia, (March 6, 2013), retrieved January 27, 2019, from https://www.documenta.hr/assets/files/objave/Civil\%20Society\%20Assessment\%20 Report\%20of\%20the\%20Croatian\%20Government\%20Performance\%20in\%20view\%20of\%20112\%20 Requests-2.pdf.

24. Enis Zebić, "Hrvatsko'za'i Susjedi: Europski Put se Isplati," Radio Slobodna Europa, (January 23, 2012), retrieved January 10, 2019, from, https://www.slobodnaevropa.org/a/nakon_hrvatskog_za_europski_ put_se_isplati/24460648.html.

25. Dejan Jović, "Accession to the European Union and Perception of External Actors in the Western Balkans," Croatian International Relations Review, Vol. 24, No. 83 (2018), pp. 6-32; Francesco Martino, "Croatia, the New, 'EU-indifferent' Member," Osservatorio Balcani e Caucaso, (June 24, 2013), retrieved January 10, 2019, from https://www.balcanicaucaso.org/eng/Areas/Croatia/Croatia-the-new-EU-indifferent-member-137241.

26. Andrew Gardner, "Croatia Backs down on Arrest Warrant," Politico, (September 25, 2013), retrieved April 18, 2019, from https://www.politico.eu/article/croatia-backs-down-on-arrest-warrant/.

27. Josip Perković was extradited to Germany in spring 2014 where in 2016 he was sentenced to life imprisonment.

29. I ascribe this argument to Dejan Jović, a political scientist, who analyzed official silence on sensitive issues in Croatia. See also, Dejan Jović, Rat i mit: Politika identiteta bu suvremenoj Hrvatskoj [War and Myth: The Politics of Identity in Contemporary Croatia], (Zaprešić: Fraktura, 2017).

30. Senada Šelo Šabić, "Croatia's Experience with Liberal Democracy," Religion \& Society in East and West, Vol. 44, No. 9-10 (2016), p. 21.

31. Marko Mrakovčić and Edgar Buršić, "Društveni Konzervativizam kao Smjerokaz Organizacije Društvenog Života [Social Conservativism as a Guideline for the Organization of Social Life]," paper presented at the Structure and Dynamics of Social Inequality, VI National Sociological Congress of Croatian Sociological Society, Zagreb, April 7-8, 2017.

32. Šelo Šabić, "Croatia's Experience with Liberal Democracy," p. 20.

33. "Convention on Preventing and Combating Violence against Women and Domestic Violence of the Council of Europe."

34. Tena Prelec, "Croatia Country Profile: Nations in Transit 2018," Freedom House, (2018), retrieved January 13, 2019, from https://freedomhouse.org/report/nations-transit/2018/croatia.

35. Snježana Pavić, "Gotovina: This Is the End: The War Belongs to the Past, Let Us Turn towards the Future," Jutarnji Online, (November 26, 2012).

36. Integral texts of judgements in the case Prlic et al. can be retrieved from http://www.icty.org/case/ prlic/4.

37. Anja Vladisavljević, "Austrian Church Bans Mass at Bleiburg Commemoration," Balkan Insight, (March 8, 2019), retrieved April 18, 2019, from https://balkaninsight.com/2019/03/08/austrian-church-bans-ma ss-at-bleiburg-commemoration/.

38. Vladisavljević, "Austrian Church Bans Mass at Bleiburg Commemoration."

39. Anja Vladisavljević, "Jasenovac Camp Victims Commemorated Separately Again," Balkan Insight, (April 12, 2019), retrieved April 18, 2019, from https://balkaninsight.com/2019/04/12/jasenovac-camp-victims-commemorated-separately-again/. 
40. "Relativisation of the Ustasha Crimes Violates the Fundamental Values of the Constitution, with a Lack of Reaction Opening Room to Hatred," Ombudsman.hr, (November 20, 2018), retrieved April 18, 2019, from http://ombudsman.hr/en/all-news/discrimination/discrimination-article/1497-relativisation-of-the-ustasha-crimes-violates-the-fundamental-values-of-the-constitution-with-a-lack-of-reaction-opening-room-to-hatred.

41. "Chris Cviic Memorial Lecture - Croatia in the EU," A lecture by Vesna Pusić delivered at EBRD Headquarters on October 18, 2012, retrieved from http://www.mvep.hr/en/info-servis/press-releases/351_2012,7517.html.

42. Senada Šelo Šabić, "Croatia," in Soeren Keil and Bernhard Stahl (eds.), The Foreign Policy of Post-Yugoslav States: From Yugoslavia to Europe, (Hampshire: Palgrave Macmillan, 2014).

43. Sven Milekić and Dejan Jović, "Croatia Must Rethink Its Foreign Policy," Osservatorio Balcani e Caucaso, (July 4, 2018), retrieved January 21, 2019, from https://www.balcanicaucaso.org/eng/Areas/Croatia/Dejan-Jovic-Croatia-must-rethink-its-foreign-policy-188806.

44. Milekić and Jović, “Croatia Must Rethink Its Foreign Policy."

45. Hrvatski Sabor, "Deklaracija o Promicanju Europskih Vrijednosti u Jugoistočnoj Europi," Narodne Novine, NN 121/2011 (2011), retrieved January 21, 2019, from https://narodne-novine.nn.hr/clanci/sluzbeni/2011_10_121_2379.html.

46. "Croatia 2011 Progress Report," European Commission, (October 12, 2011), retrieved April 18, 2019, from https://ec.europa.eu/neighbourhood-enlargement/sites/near/files/pdf/key_documents/2011/ package/hr_rapport_2011_en.pdf, p. 14.

47. Milekić, and Dejan Jović, "Croatia Must Rethink Its Foreign Policy."

48. Interview with an EU diplomat (Zagreb, April 2019).

49. "EU Coalition Explorer 2018," European Council on Foreign Relations, (2018), retrieved from https:// www.ecfr.eu/eucoalitionexplorer. ECFR runs an interactive and comprehensive website which includes tables and graphs with analyzed results, as well as sections with raw data.

50. "A Credible Enlargement Perspective for and Enhanced EU Engagement with the Western Balkans," European Commission, (February 6, 2018), retrieved April 15, 2019, from https://ec.europa.eu/commission/sites/beta-political/files/communication-credible-enlargement-perspective-western-balkans_ en.pdf, p. 3.

51. Milada Anna Vachudova, "EU Enlargement and State Capture in the Western Balkans."

52. Judy Dempsey, "Judy Asks: Is Central Europe Damaging EU Enlargement?" Carnegie Europe, (February 28, 2018), retrieved April 22, 2019, from https://carnegieeurope.eu/strategiceurope/75667?lang=en. 


\section{SETA}

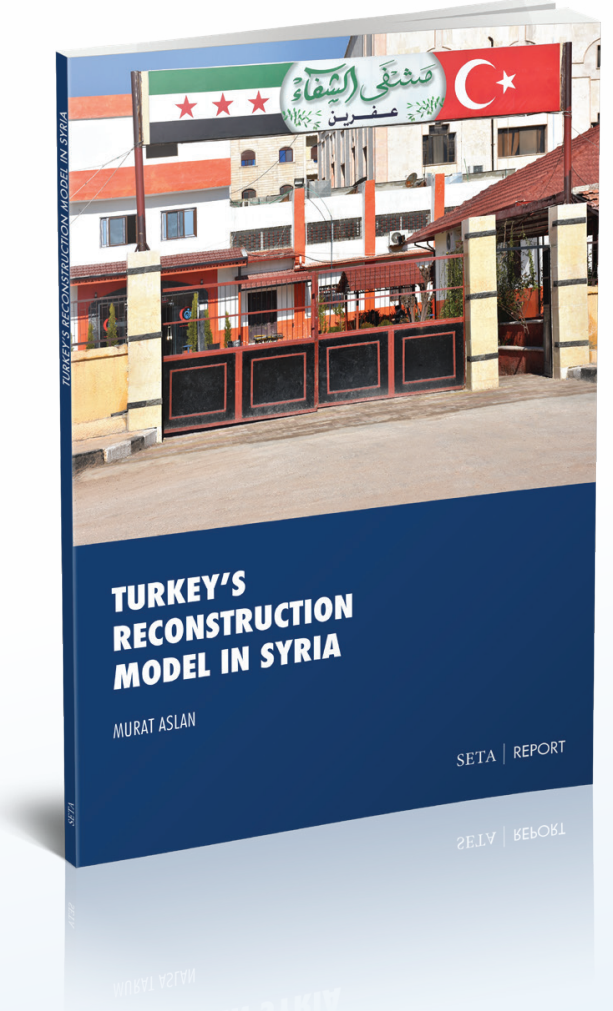

SETA Security Radar

Turkey's Security Landscape in 2019

Murat Yeşiltaş, Murat Aslan, Ömer Özkizilcik, Selen Öztürk, Rıfat Öncel, Sibel Düz, Ümit Tetik, Melis Ege Kunt, Pınar Demirci

This work aims to provide a timely and accessible assessment of the challenges awaiting Turkey in 2019. Hence, SETA Security Radar: Turkey's Security Landscape in 2019 pertains to the following topics: Turkey's role in Syria, Turkey's counterterrorism strategy, Turkey's military activism, the Turkish defense agenda, Turkey and the Eastern Mediterranean, and Turkey's bilateral relations with the United States and Russia.

\section{Turkey's Reconstruction Model in Syria}

Murat Aslan

The objective of this report is to scrutinize the effectiveness of the reconstruction efforts as part of Turkey's security-oriented active policies in the light of the developments in Syria.

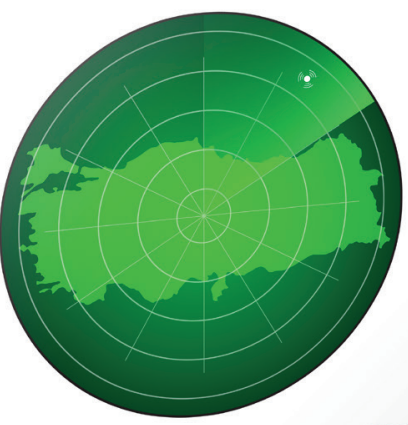

